\title{
Measurement of Satisfaction in Sustainable Tourism: A Cultural Heritage Site in Spain
}

\author{
Nuria Huete-Alcocer ${ }^{1}\left[\right.$, Víctor Raúl López-Ruiz ${ }^{1}$ 通 and Adriana Grigorescu ${ }^{2, *}$ \\ 1 Faculty of Economics and Business, Plaza de la Universidad N $N^{o}$, University of Castilla-La Mancha, \\ 02071 Albacete, Spain; Nuria.Huete@uclm.es (N.H.-A.); Victor.Lopez@uclm.es (V.R.L.-R.) \\ 2 Valahia University from Targoviste, Institute of Economic Forecasting-Romanian Academy, 012244 \\ Bucharest, Romania \\ * Correspondence: adriana.grigorescu@snspa.ro
}

Received: 8 November 2019; Accepted: 28 November 2019; Published: 29 November 2019

\begin{abstract}
Sustainable tourism, in the cultural context, is a fundamental element for the economic development of some local communities. There are many factors that can influence the success of this type of tourism, but any action or strategy adopted should be closely related to the satisfaction of the tourist. This research focuses on a heritage destination of an archaeological nature, and is aimed at analyzing the profile of the cultural tourist and his/her level of satisfaction after visiting the site. Information was collected using a closed questionnaire given to tourists. An ANOVA analysis has been used to determine the relationship between sociodemographic characteristics and satisfaction, with significant results found in relation to gender and income level. This study has helped to highlight what underlies the differences in tourists' post-visit satisfaction. These analyses have provided information that can be used in the planning of future sustainable tourism marketing strategies; thus, this study provides some recommendations on how to improve the provision of services and the management of these types of heritage elements.
\end{abstract}

Keywords: cultural tourism; cultural tourist; cultural heritage; satisfaction

\section{Introduction}

The importance of tourism in Spain is reflected in the number of tourist arrivals to this country in 2018. According to data collected from [1], the number of foreign visitor arrivals in 2018 was over 82.6 million, which represents an increase of $1.1 \%$ over the previous year. As a result, Spain has become the second-ranked country in the world in terms of foreign visitor arrivals [2,3]. However, the influx of tourists is not only due to traditional sun and beach tourism offers, but other types such as cultural tourism.

Nowadays, this type of heritage tourism, which is viewed as sustainable, is being very successfully developed in this country [4]. In this regard, the United Nations Organization for Education, Science and Culture (UNESCO) reports that tourism focusing on natural and cultural heritage is the area that has experienced the greatest growth in the tourism industry [5]. Moreover, heritage tourism has been largely considered as a form of experiential consumption in recent years [6].

An essential element that can be enjoyed as part of a tourist activity is the experiences that result from the tourist coming into contact with the culture of a specific place, more specifically with the local heritage [7]; in many cases, this refers to the local archeology [8]. To a great extent, the success of a tourist destination depends on the interactions between visitors and local residents [9]. In this sense, an especially important contribution of local residents is when they offer a cultural interchange with visitors who are eager to learn about the heritage of the place. This has been shown in a number of studies [10] that suggest support should be provided to help tourists develop emotional bonds with 
places, and connections with those residing in the destination. These ties to places and the feeling of solidarity with local residents can positively influence visitors' sense of loyalty to the destination. Thus, such connections can be considered a way of ensuring the sustainability of tourism within a particular community [11].

Since the end of the 20th century, heritage destinations have been receiving substantial numbers of visitors, as the cultural heritage of a place is a large part of what attracts tourists to a particular location, as well as being representative of the identity of the local society [12]. Currently, the consumption of cultural products, such as historical and artistic heritage and monuments, is attracting growing attention from academics and researchers due to the complexity of this type of tourism [13]. Indeed, the demand for cultural products is continuously evolving in terms of tourists' consumption habits, sociodemographic characteristics, motivations and expectations, among other aspects $[14,15]$. In this regard, cultural tourism can be understood as the "visits by persons from outside the host community motivated wholly or in part by interest in the historical, artistic, scientific or lifestyle/heritage offerings of a community, region or institution" [16].

As a model of cultural tourism, the city of Segóbriga is the focus of analysis in this research. Located in the province of Cuenca (Spain), it is a Roman site listed as an archaeological park. This study focuses on sustainable tourism, in the cultural context, with the main objective being to determine how elements of the visitor profile affect the satisfaction of the tourist who visits the archaeological park of Segóbriga. The results reveal the relationships between certain sociodemographic variables that define the profile of the visitor to this site-namely, age, gender, income level, educational level, employment status-and the degree of tourist satisfaction. The sample consists of 408 tourists visiting the park in the spring of 2017. For the data collection, a questionnaire was used that included satisfaction scales previously used by several authors in their research (e.g., [17-20]).

This study helps to determine what kind of tourists visit this archaeological site, what their profile looks like and how best to reach them. The results of the study also offer information that may be helpful when it comes to improving the tourism product or designing better marketing, which in turn will support the socioeconomic development of the local area.

Regarding tourist satisfaction, the literature on this subject highlights the importance of this variable as a strong indicator of tourists' intentions to come back to visit a destination or recommend it [21,22].

\section{Literature Review}

\subsection{Cultural Tourism and Sustainable Development}

The strong growth of the tourism sector in recent years has led to the sustainability of this industry being widely addressed in the literature [23-25]. Some authors [26,27] consider sustainable development in tourism to be closely related to environmentally-responsible tourism. In this sense, it is clear that ensuring the sustainability of tourism can be considered as one of the most effective ways to achieve the development of communities in tourist destinations, with local populations playing a key role in this regard. Local residents may even be able to bring about changes in the pattern of visitor arrivals, or foster innovations by taking advantage of the natural and cultural resources of the area [28]. In this way, it is not only the culture itself that is important, but also the local residents who can offer a cultural exchange with tourists interested in learning about the heritage of the place [10].

Cultural curiosity has traditionally been the basis for tourism development and the increase in mobility among tourist consumers [13]. In recent years, this type of sustainable tourism has become one of the largest segments of the tourism market, reflecting the notable growth in the level of demand for tourism products centering on cultural values [29]. Therefore, today heritage is considered as an economic resource and is valued as a key development factor in the context of a new approach to tourism. 
The complexity of the concept of cultural tourism has led to multiple definitions and perspectives, depending on the author or researcher [30]. Some of them (e.g., [31]) describe it as people traveling to places of cultural interest, with the aim of obtaining information and new experiences to meet their cultural needs. More generally, [32] defines it as a type of trip for personal enrichment. However, other researchers opt for a much tighter concept and focus on cultural services or products consumed by the tourist, regardless of the motivation for the trip [33,34]. Others such as [30] claim that a tourist who consumes a cultural product is a cultural tourist by definition. This product thus incorporates the components that attract tourists of a particular nature and with specific personal characteristics (each of them comprises a different subgroup with different needs in terms of experiencing the culture). This also allows for the satisfaction of needs related to traveling to and staying in a certain place, that is, the set of goods and services that enable trips made for cultural purposes.

A common aspect stands out in all these definitions: the cultural tourist's interest in finding out about diverse cultural elements; that is, elements of cultural heritage [35], understood as the set of tangible elements such as museums and historical and archaeological sites, as well as intangible elements such as traditions, ways of life, and language, which constitute the identity of a place [36]. This gives rise to the interest in studying the profile of the cultural tourist seeking to learn about the culture of a place.

\subsection{The Profile of the Cultural Tourist}

A review of the related literature shows a great variety of characteristics that can be identified within the profile of the cultural tourist [12]. Some studies (e.g., [37,38]) suggest that some tourists may be more motivated than others to engage in a cultural experience, and their degree of involvement in the historical-cultural experience may vary. As such, [34] identify five types of cultural tourists, classified according to their motivation for travel (Table 1):

Table 1. Types of cultural tourists.

\begin{tabular}{ll}
\hline \multicolumn{1}{c}{ Type of Tourist } & \multicolumn{1}{c}{ Definition } \\
\hline Complete cultural tourist & $\begin{array}{l}\text { One who seeks a much deeper cultural experience, with cultural tourism being the main } \\
\text { motivation for the visit. }\end{array}$ \\
\hline Cultural visitor & $\begin{array}{l}\text { Although the main motive for visiting a destination is cultural tourism, they are not seeking } \\
\text { such a profound experience. }\end{array}$ \\
\hline Cultural discoverer & $\begin{array}{l}\text { This tourist does not travel for cultural reasons but ends up having a deep } \\
\text { cultural experience. }\end{array}$ \\
\hline Cultural casual & Seeks some cultural activity on their trip, although this is not the main reason for it \\
\hline Cultural accidentally & $\begin{array}{l}\text { This tourist's main motive for travel is not cultural, but by chance they end up participating } \\
\text { in this activity, albeit not in a profound way. }\end{array}$ \\
\hline
\end{tabular}

From the above, it can be seen that there are two main types of cultural tourists in terms of motivation: those motivated by culture and those motivated by leisure. One type of cultural tourist is motivated by culture; that is, they view the trip as an opportunity for personal development and experiences that allow the achievement of that objective. Conversely, occasional cultural tourists, or cultural tourists by chance, are not motivated by culture, but rather see the trip as a leisure experience [37]. Other authors (e.g., [39]) have also analyzed tourists' motivations for making a cultural visit, contributing to a profile of this type of visitor characterized by high income level and motivated by other cultural initiatives such as attending a festival, visiting monuments or meeting people from cultures and places, with determining factors including origin, age or educational level. Other relevant features of the cultural tourist include his/her openness to encounters with local residents [10], higher level of education [40], higher income level [30], as well as certain sociodemographic characteristics that are the subject of this research. Some authors claim that the profile of the cultural tourist in Spain is of average age (between 25 and 44 years old), without a significant difference between the sexes, and demanding very short stays [35]. The main objective of this research is to determine the profile of the 
tourist that travels to these areas of heritage interest in terms of their sociodemographic characteristics, but regardless of the reason for the trip.

\subsection{Tourist Satisfaction and Sociodemographic Characteristics of Cultural Tourists}

Cultural tourism is a popular target of tourism policymakers because it supposedly attracts high-quality, high-value tourists while providing economic support for the local culture. This growing interest in tourists visiting cultural attractions is partly out of necessity, and also due to the fact that cultural tourism is seen as an important growing market [41]. The positive trends observed in the increase in cultural tourism together with the profile of tourists interested in cultural heritage are linked to a need to revitalize the cultural heritage sector [42]. In this sense, it is important to take into account the profile of the tourist, as it has been shown that their sociodemographic characteristics can define not only cognitive and affective responses, but also behavioral responses [9]. For example, gender is known to influence information processing strategies [43], while the image of the destination is influenced by age, income, gender, race, nationality and education [44-47]. Another example is the study by [48], who finds gender differences in expectations regarding sustainable practices, while in a subsequent study [49] she reports similar differences in consumer-based brand equity.

On the other hand, the review of the relevant literature shows that tourism researchers have carried out extensive studies to analyze the dependence of tourist satisfaction on their sociodemographic characteristics [50]. It has been assumed that culture influences tourism behavior, but due to the difficulty of measuring cultural values directly at the individual level, the relationship between the tourist's cultural profile, taking into account some sociodemographic variables, and their satisfaction after the visit has not yet been tested empirically.

The concept of satisfaction in tourism, or tourist satisfaction can be understood as the difference derived from the comparison between the individual's expectations and his/her actual tourist experience $[22,51,52]$. In this study, satisfaction is defined as the overall satisfaction of a tourist with the visit experience in a cultural heritage site [6]. Furthermore, satisfaction positively affects behavioral intentions. This can be interpreted as satisfied tourists being more likely to have behavioral intentions to make a return visit or return to the heritage site. However, some studies (e.g., [53]) have suggested that not all the attributes of the products or services are equally relevant when it comes to interpreting customer satisfaction. Other authors (e.g., [18]) conclude that the level of satisfaction depends on the human factor and the assessment of the accessibility of the services provided, with the former being where satisfaction is most evident. Therefore, in cultural tourism, quality and the provision of resources plays an extremely important role in determining tourist satisfaction. Previous studies show how the level of satisfaction with visiting a place is the result of different factors evaluated by the comparison between the tourist's perceptions of the product or service received during the visit and their expectations prior to the visit, and influenced by their sociodemographic characteristics [54,55]. In short, the tourist can have different levels of satisfaction [22], depending in part on the characteristics of the visitor; hence the interest in this study in analyzing this relationship.

Having theoretically analyzed satisfaction as a dependent variable in this research, the sociodemographic factors of tourists that can influence their level of satisfaction are examined, and specifically the items used to measure each factor. To this end, a total of five hypotheses are proposed, based on the theoretical framework detailed below.

Gender, employment status, level of education, income and age are individual-level variables that play a specific role in the perception of tourist destinations [45,56-58]. Numerous studies (e.g., [46,58]) have suggested how these variables significantly influence tourists' perceptions and can be considered a filter, such that the perception varies according to the person or tourist [58]. For example, some authors, such as [59], have found significant differences in tourist satisfaction with respect to gender. Others such as [39] argue that women are more attracted to tourism resources than men, which is why they tend to have a higher level of satisfaction [21]. Regarding age, tourists' degree of satisfaction also differs in relation to this characteristic. For example, [21] suggest that older people have a higher level 
of satisfaction than younger people. Others such as [20] reach the conclusion that age has an influence on certain variables relating to satisfaction, especially in tourists aged over 45 . In general, numerous researchers (e.g., [57]) have shown that the age of the tourist affects their perception of a destination and their post-visit satisfaction. Nevertheless, others, such as [44], confirmed that the characteristics of the gender and income level have no such influence. Conversely, [58] show that tourists' income level and employment status are the factors that can most influence perceptions of a place, which may in turn be reflected in tourists' level of satisfaction.

Regarding the latter arguments, the literature review reveals that there has been little tourism research to date that demonstrates how other sociodemographic characteristics influence tourist satisfaction. Some of the few examples include the study by [20], investigating the influence of gender, age and nationality on satisfaction; or that of [19], who examine the role played by age, gender, income level of or salary, origin and employment status of the visitor in their degree of satisfaction. Apart from age and gender, this study analyzes educational level, employment status and income level. Thus, in light of the above, this research proposes the following hypotheses aimed at testing whether the profile of the tourist makes a difference to the satisfaction of their visit:

Hypothesis 1. There are differences in the satisfaction of the cultural tourist with respect to gender.

Hypothesis 2. There are differences in the satisfaction of the cultural tourist with respect to age.

Hypothesis 3. There are differences in the satisfaction of the cultural tourist with respect to the highest level of education.

Hypothesis 4. There are differences in the satisfaction of the cultural tourist with respect to employment status.

Hypothesis 5. There are differences in the satisfaction of the cultural tourist with respect to income level.

\section{Materials and Methods}

\subsection{Description of the Site}

The city of Segóbriga is the most important archaeological site on the southern plateau in Spain, and one of the best preserved Roman cities from the western Roman Empire. This archaeological park is highly appreciated as a sustainable tourist destination. There are also many other attractions located not only in the Cuenca capital, but also in the surrounding area (Uclés, Ercávica, Valeria, etc.). The findings of the archaeological excavations that have been carried out over time have helped to illustrate the history of this site. The enclave stands out not only due to its archaeological interest but also the surrounding landscape, because the landscape physiognomy remains essentially the same as it was in Roman times. Visitors can thus enjoy the walk through the archaeological remains and at the same time admire a natural environment of remarkable beauty.

\subsection{Research Instrument and Data Collection}

The review of the literature on satisfaction has provided theoretical guidance on how to measure this variable, and this study has subsequently used indicators and factors drawn from previous research (e.g., [17-20]. The measurement of this variable is based on a number of factors, which in turn are made up of several items. The first factor, overall satisfaction (factor 1), was taken from the study by [60], where tourists had to "indicate their overall satisfaction with the experience in this archaeological destination". This factor could be considered the most relevant. Together with the assessment of overall satisfaction, a more specific, individual scale was constructed to analyze visitor satisfaction with all the services provided by the park, such that the tourist evaluated their experience by indicating their degree of satisfaction or dissatisfaction with 24 items, giving rise to a total of five more factors: (2) road infrastructure, (3) the hotel infrastructure, (4) restoration infrastructure, (5) conservation of 
the site and (6) the information received and the treatment from the staff. This scale was constructed by selecting some of the items used by $[17,18]$ in their research. To measure both overall satisfaction and these last five factors, a five-point scale was used, ranging from 1 for "very unsatisfied" to 5 for "very satisfied".

All the questions that were used to measure these factors were included in a questionnaire written based on an exhaustive review of the literature and the specific characteristics of the destination under study. The questionnaire was used to gather information from site visitors after their visit. The data was collected over four consecutive weekends during the months of April and May 2017. A total of 408 questionnaires were given out to tourists aged 18 and over, Previously, a pilot test was conducted in order to refine the questionnaire and make the necessary changes.

\subsection{Data Analysis}

The analyses in this research were carried out with SPSS Statistics 24.0 software. First, exploratory factor analysis (EFA) was carried out using the Varimax rotation method, the aim of which was to validate the scale for each variable or factor that measures satisfaction.

After validating these scales, a univariate analysis of variance (ANOVA) was performed, which reveals the differences between the means of a continuous dependent variable and categorical independent variables. In this case, the sociodemographic variables have been taken as independent variables, while the dependent variables are each of the items comprising the factors that measure satisfaction; that is, the dependent variable is the tourist's post-visit satisfaction. See supplementary materials.

\section{Empirical Results}

Based on the results obtained from the EFA (through Varimax rotation), the scale for each variable or factor measuring satisfaction can be validated. Of the six factors mentioned above, this analysis validated only three (Table 2): (1) the overall satisfaction with the visit (measured with only one item), (2) satisfaction with the road, hospitality, restoration and conservation infrastructure (measured with 12 items) and (3) satisfaction with the accessibility of tourist information and treatment received (measured with 12 items).

The analysis of the data obtained through the questionnaires answered by the 408 tourists surveyed after their visit to Segóbriga, revealed that $55.4 \%$ were women and $44.6 \%$ were men. As for the most common place of origin of the respondents, $50.7 \%$ were from the Madrid region, 15\% from Castilla-La Mancha and $13.5 \%$ from the Valencian Community. Most visitors were aged between 40 and 59 years, $67.9 \%$ of the total sample, with the youngest age range-between 18 and 25 years old - accounting for $3.4 \%$ of the total. Regarding respondents' level of education, most had higher education, with more than half of the sample, $63 \%$, holding a university degree and $5.1 \%$ also holding a doctorate. Tourists who do not have any type of studies represents only $0.5 \%$. These figures confirm that almost all visitors have the highest level of education. Regarding the employment status of visitors, salaried workers are in first place $(32.6 \%)$, followed by the group of public officials $(18.6 \%)$, workers with titling $(15.7 \%)$ and self-employed workers (11\%). Of all the respondents, $29.2 \%$ have a gross annual income in the range of $€ 15,000$ to $€ 30,000$, while $56.4 \%$ exceed $€ 30,000$ per year. Those that report an annual income of less than $€ 15,000$ represent $14.5 \%$ of the total. In conclusion, the profile of the tourist visiting Segóbriga can be described as usually a female, between 40 and 59 years old, who works, with a fairly high income and highest level of education.

The ANOVA analysis has been used to accept or reject the null hypothesis (H0) of independence between the variables. In parallel, the Chi-square test was also performed (bilateral asymptotic significance) to corroborate the differences between the mean scores of these factors. 
Table 2. Factors for measuring satisfaction and individual items.

\begin{tabular}{|c|c|c|c|c|c|c|}
\hline Factors & Item & Loadings & Variance $\%$ & Cronbach $\alpha^{1}$ & $\mathrm{KMO}^{2}$ & $\begin{array}{c}\text { Sig. } \\
\text { (Significance) }\end{array}$ \\
\hline Overall satisfaction & Overall visit satisfaction & 1.000 & 100 & N/A & N/A & $\mathrm{N} / \mathrm{A}$ \\
\hline \multirow{12}{*}{$\begin{array}{l}\text { Satisfaction with road, } \\
\text { hotel, restoration and } \\
\text { conservation } \\
\text { infrastructure. }\end{array}$} & Area where it is located & 0.320 & \multirow{12}{*}{40.75} & \multirow{12}{*}{0.710} & \multirow{12}{*}{0.714} & \multirow{12}{*}{0.00} \\
\hline & Public transport & 0.506 & & & & \\
\hline & Private transport & 0.712 & & & & \\
\hline & Internal Accesses & 0.387 & & & & \\
\hline & Restaurants & 0.814 & & & & \\
\hline & Accommodation and hotels & 0.781 & & & & \\
\hline & Structures of the site & 0.639 & & & & \\
\hline & Museum & 0.657 & & & & \\
\hline & Historical buildings & 0.595 & & & & \\
\hline & Maintenance & 0.712 & & & & \\
\hline & Cleanliness & 0.759 & & & & \\
\hline & Security service of the site & 0.442 & & & & \\
\hline \multirow{12}{*}{$\begin{array}{l}\text { Satisfaction with access } \\
\text { to tourist information } \\
\text { tourist and treatment } \\
\text { received }\end{array}$} & Park information & 0.625 & \multirow{12}{*}{74.73} & \multirow{12}{*}{0.829} & \multirow{12}{*}{0.838} & \multirow{12}{*}{0.00} \\
\hline & $\begin{array}{l}\text { Information on leisure } \\
\text { activities in the area }\end{array}$ & 0.485 & & & & \\
\hline & Information on local customs & 0.409 & & & & \\
\hline & $\begin{array}{l}\text { Information about } \\
\text { local cuisine }\end{array}$ & 0.658 & & & & \\
\hline & Festival Information & 0.794 & & & & \\
\hline & Concert Information & 0.850 & & & & \\
\hline & Information on crafts & 0.707 & & & & \\
\hline & Folklore information & 0.795 & & & & \\
\hline & Guided tours & 0.564 & & & & \\
\hline & Personal treatment received & 0.707 & & & & \\
\hline & Quality of life in the area & 0.696 & & & & \\
\hline & Park access price & 0.563 & & & & \\
\hline
\end{tabular}

Source: authors' own elaboration.

Table 3 shows the results of the ANOVA analysis of the independence of the satisfaction variable, measured through three factors composed of a total of 25 items regarding the sociodemographic characteristics under study. These results also allow an evaluation of tourists' average overall satisfaction with their experience of visiting the archaeological park, which is 4.4 out of 5 . 
Table 3. Results of the ANOVA analysis: sociodemographic characteristics-satisfaction.

\begin{tabular}{|c|c|c|c|c|c|c|c|c|c|c|c|}
\hline \multirow{2}{*}{ Factors } & \multirow{2}{*}{ Item } & \multicolumn{2}{|c|}{ Gender } & \multicolumn{2}{|c|}{ Age } & \multicolumn{2}{|c|}{ Studies } & \multicolumn{2}{|c|}{ Employment } & \multicolumn{2}{|c|}{ Income } \\
\hline & & F & Sig. & F & Sig. & F & Sig. & F & Sig. & F & Sig. \\
\hline $\begin{array}{l}\text { (1) Overall } \\
\text { satisfaction }\end{array}$ & Overall satisfaction with the visit & 3.13 & 0.077 & 0.598 & 0.616 & 0.557 & 0.764 & 0.984 & 0.453 & 0.554 & 0.696 \\
\hline \multirow{12}{*}{$\begin{array}{l}\text { (2) Satisfaction with } \\
\text { road, hotel, } \\
\text { restoration and } \\
\text { conservation } \\
\text { infrastructure. }\end{array}$} & Area where it is located & 2.51 & 0.113 & 0.422 & 0.737 & 1.72 & 0.113 & 0.842 & 0.578 & 1.83 & 0.121 \\
\hline & Public transport & 0.799 & 0.372 & 0.539 & 0.656 & 1.06 & 0.381 & 0.729 & 0.682 & 1.01 & 0.402 \\
\hline & Private transport & 0.279 & 0.598 & 1.26 & 0.286 & 3.49 & 0.002 & 2.48 & 0.009 & 3.02 & 0.018 \\
\hline & Internal accesses & 0.201 & 0.654 & 1.74 & 0.156 & 1.52 & 0.170 & 1.23 & 0.270 & 0.598 & 0.664 \\
\hline & Restaurants & 0.072 & 0.789 & 1.71 & 0.163 & 1.15 & 0.329 & 1.96 & 0.042 & 2.67 & 0.032 \\
\hline & Accommodation and hotels & 0.085 & 0.771 & 3.48 & 0.016 & 1.88 & 0.083 & 1.81 & 0.064 & 2.39 & 0.050 \\
\hline & Structures of the site & 0.357 & 0.551 & 2.24 & 0.083 & 0.67 & 0.999 & 1.28 & 0.242 & 0.431 & 0.786 \\
\hline & Museum & 2.36 & 0.125 & 0.492 & 0.688 & 0.167 & 0.985 & 0.774 & 0.641 & 2.32 & 0.056 \\
\hline & Historical buildings & 1.49 & 0.222 & 2.37 & 0.070 & 1.19 & 0.308 & 1.93 & 0.046 & 0.645 & 0.631 \\
\hline & Maintenance & 3.42 & 0.065 & 1.72 & 0.162 & 0.360 & 0.904 & 0.607 & 0.791 & 0.419 & 0.795 \\
\hline & Cleanliness & 2.06 & 0.151 & 0.249 & 0.862 & 0.927 & 0.475 & 1.19 & 0.296 & 5.78 & 0.000 \\
\hline & Site security service & 0.001 & 0.976 & 0.569 & 0.636 & 1.58 & 0.150 & 1.72 & 0.081 & 1.33 & 0.256 \\
\hline \multirow{12}{*}{$\begin{array}{l}\text { (3) Satisfaction with } \\
\text { access to tourist } \\
\text { information tourist } \\
\text { and treatment } \\
\text { received. }\end{array}$} & Park information & 1.20 & 0.273 & 0.938 & 0.422 & 1.37 & 0.225 & 1.34 & 0.212 & 3.55 & 0.007 \\
\hline & $\begin{array}{l}\text { Information on leisure activities } \\
\text { in the area }\end{array}$ & 1.93 & 0.165 & 3.80 & 0.010 & 0.712 & 0.640 & 0.751 & 0.662 & 0.583 & 0.675 \\
\hline & Information on local customs & 2.45 & 0.118 & 0.737 & 0.531 & 1.23 & 0.287 & 1.84 & 0.059 & 1.59 & 0.175 \\
\hline & Information about local cuisine & 0.077 & 0.781 & 3.23 & 0.022 & 2.33 & 0.032 & 2.45 & 0.010 & 8.31 & 0.000 \\
\hline & Festival Information & 2.02 & 0.156 & 3.57 & 0.014 & 2.27 & 0.036 & 1.64 & 0.098 & 8.13 & 0.000 \\
\hline & Concert Information & 3.35 & 0.068 & 2.65 & 0.048 & 1.02 & 0.410 & 0.816 & 0.602 & 5.31 & 0.000 \\
\hline & Information on crafts & 0.266 & 0.607 & 0.844 & 0.471 & 0.293 & 0.940 & 0.915 & 0.512 & 3.00 & 0.018 \\
\hline & Folklore information & 6.83 & 0.009 & 1.16 & 0.322 & 2.52 & 0.958 & 0.978 & 0.461 & 3.07 & 0.016 \\
\hline & Guided tours & 0.05 & 0.822 & 0.939 & 0.422 & 0.382 & 0.890 & 0.816 & 0.601 & 0.998 & 0.409 \\
\hline & Personal treatment received & 0.000 & 0.986 & 1.82 & 0.142 & 0.969 & 0.446 & 0.846 & 0.574 & 0.163 & 0.957 \\
\hline & Quality of life in the area & 1.80 & 0.180 & 1.67 & 0.172 & 1.29 & 0.260 & 1.31 & 0.230 & 2.37 & 0.051 \\
\hline & Park access price & 0.800 & 0.371 & 4.81 & 0.003 & 0.837 & 0.542 & 3.75 & 0.000 & 5.81 & 0.000 \\
\hline
\end{tabular}

Source: authors' own elaboration. Bold values are showing significant differences. 
On the other hand, the Chi-square test reveals the following points in relation to the results of the ANOVA analysis presented in Table 3:

(a) Gender: of all the tourists surveyed in the archaeological park, women report a greater degree of satisfaction than men. The results of the ANOVA show that there are significant differences between men and women for only a single item of the 25 considered to assess satisfaction; namely, the satisfaction of the tourist regarding access to information on local folklore (an item corresponding to factor 3). Therefore, said analysis reveals that the rest of the factors of satisfaction (road, hospitality, restoration and conservation infrastructure and overall satisfaction) do not present differences with respect to gender. However, the results of the Chi-square statistic show significant differences with respect to gender for two of the items corresponding to factor 3 . These are access to information on theater festivals (sig 0.02) and the concerts held in the park (sig 0.05). This finding partly coincides with the study by [20] on the city of Madrid as a tourist destination, where the only significant differences found between men and women were in the satisfaction in the access to tourist information about said destination. Regarding the tourists' overall satisfaction (factor 1), this statistic does show differences with respect to gender (sig 0.025). Therefore, it can be confirmed that research hypothesis H1 is accepted; even though it is measured with only one factor, it refers to the overall satisfaction with the visit to the park, and so it can be confirmed that gender influences the satisfaction of the tourist.

(b) Age: the analysis of the influence of age on satisfaction reveals significant differences in the following items: accommodation and hotels (items corresponding to factor 2), access to information on cuisine, leisure activities in the area, concerts, festivals and the price of the entrance to the park (items corresponding to factor 3 ). These results were also checked with the Chi-square test, corroborating that all of these are dependent on age. The latter test also adds others not identified by the ANOVA analysis: accommodations and hotels (sig 0.003) site structures (sig 0.001) and historical buildings (sig 0.001 ) (corresponding with factor 2); and access to information on local customs (sig 0.02), cuisine (sig 0.002), festivals (sig 0.004), concerts (0.019), crafts (sig 0.008), guided tours through the park (sig 0.029), personal treatment received (sig 0.000) and the price of access to the site (sig 0.005) (all corresponding to factor 3). Regarding factor 1, the overall satisfaction of the tourist, the ANOVA analysis did not find a substantial difference. The latter finding was also corroborated with the Chi-square statistic (sig 0.673). Based on these results, research hypothesis $\mathrm{H} 2$ cannot be accepted. Therefore, age does not influence the degree of satisfaction. The results were similar in the related study by [20], as these authors came to the conclusion that the degree of satisfaction with access to tourism information and accessibility does not present differences in relation to age. This result was also confirmed by the study by [19], who indicate that the tourist's age does not affect their level of satisfaction.

(c) The highest level of education (studies): as shown in the ANOVA results in Table 3, this characteristic of tourists has an influence on three elements used to measure satisfaction with the visit to the archaeological park of Segóbriga. These items are the access to the site via private transport (item corresponding to factor 2 of satisfaction), access to information on local cuisine and on festivals (factor 3). Regarding factor 1, overall satisfaction, this analysis does not confirm a relationship between this variable and the tourist's educational level. This finding is corroborated by the Chi-square statistic (sig 0.212). After applying the Chi-square test to check the ANOVA for factors 2 and 3 according to the tourist's level of education, the results confirmed a relationship between this sociodemographic characteristic and the following items: internal access (sig 0.000) and cleanliness (sig 0.024) (factor 2); and access to park information (sig 0.44), cuisine (sig 003), festivals (sig. 0.003), crafts (sig 0.04) and quality of life in the area (sig 0.02) (factor 3). Based on these results, H3 is not accepted. The findings related to this hypothesis could not be compared with other studies, since to date there have been no such studies; namely, analyzing whether the tourist having the highest level of education influences their level of satisfaction.

(d) Employment status: Regarding factor 1, the overall satisfaction of the tourist, the ANOVA analysis does not present independence regarding the work situation of the tourist. This was verified with the Chi-square test, which corroborated that there are no significant differences (sig 0.422). As for 
the other two factors that measure satisfaction, of the 24 items used, the ANOVA finds significant differences for only for 5 items with respect to the employment status of the tourist. Regarding factor 2 , differences are found regarding access to the park via private transport, restaurants and historical buildings. Regarding factor 3, there are differences in the access to information on local cuisine and the price of the entrance. These findings were checked with the Chi-square test, which ultimately only corroborated the access to the park by private transport (sig 0.00), historical buildings (sig 0.48 ), the security service (0.028) and the accesses inside the park (sig 0.002) (factor 2); access to information on local cuisine (sig 0.000), access to information on local customs (sig 0.028), festival information (sig 0.013), and the quality of life in the area (sig 0.004) (factor 3). In view of the results, it can be said that $\mathrm{H} 4$ is not accepted; that is, the tourist's employment status does not influence their satisfaction. These are quite the opposite of the results obtained by [58], who showed that the tourist's level of income and employment status are the factors that most influence their perception of a place, which in turn could be reflected in the level of tourist satisfaction. Others such as [19], showed that the tourist's employment status or job situation can have a negative impact on their level of satisfaction; for example, if they are a student or unemployed.

(e) Income level: unlike the characteristics addressed above, the ANOVA analysis finds that the tourist's level of income has the greatest influence on their degree of satisfaction with the items measured in factors 2 and 3; indeed, the ANOVA does not find any dependence between the overall satisfaction of the tourist (factor 1) and level of income. The relevant items in factor 2 are: access to the park via private transport, restaurants, accommodation and hotels and cleanliness of the facilities. The items in factor 3 are: access to park information, access to information on local cuisine, concerts, festivals, folklore, craftsmanship, the quality of the area in which it is located and the price of admission to the enclosure. These results were corroborated with the Chi-square test, which confirmed that factor 1 does not show a significant difference with respect to the level of income (sig 0.323), but does with respect to some items of factors 2 and 3 . This test confirmed that there is dependence between income level and the following items corresponding to factor 2: accesses inside the park (sig 0.019), structures of the site (sig 0.000), museum (sig 0.000), historical buildings (sig 0.000), maintenance (0.049), cleanliness (sig 0.000) and the security service on the premises (sig 0.019). The Chi-square test also showed dependence between income level and the following items from factor 3: the access to information on the park (sig 0.025), local customs (sig 0.000), cuisine (sig 0.000), theater festivals (sig 0.000), concerts (sig 0.001), crafts (sig 0.013), folklore (sig 0.003), guided tours of the site (sig 0.000); as well as the personal treatment received (sig 0.000), the quality of life in the area (sig 0.000$)$ and the price of the entrance to the site (sig 0.000). In view of these results, that is, since most of the items are found to be dependent on this variable-although it is not the case regarding the overall satisfaction of the tourist (factor 1) - it could be claimed that tourists' income level influences their level of satisfaction; thus, $\mathrm{H} 5$ can be accepted.

\section{Discussion}

The results obtained indicate which sociodemographic variables affect the satisfaction of the cultural tourist, and contradict some of the research carried out so far. The results on gender obtained in this study are contrary to those of [19], who reported that gender has no effect on tourists' level of satisfaction. However, the results obtained regarding age confirmed the study by [19], who indicated that the tourist's age does not have any effect on their level of satisfaction.

On the other hand, it was found that having the highest level of education does not influence tourists' level of satisfaction. However, this finding could not be compared with other studies, since no other analyses to date have focused on this element.

Regarding the results obtained on employment status, they contradict the study by [58], who showed that tourists' level of income and employment status are the factors that most influence the perception of a place, which in turn may be reflected in the level of tourist satisfaction. Others such 
as [19] showed that the tourist's employment status or job situation of the tourist can have a negative impact on their level of satisfaction, for example, in the case of being a student or being unemployed.

Likewise it was found that tourists' income level influences their level of satisfaction. The same finding was reported in the investigation carried out by [19], where the level of income was found to have a positive influence on tourist satisfaction. This could confirm the hypothesis that a more positive degree of satisfaction is associated with a higher salary. As commented above, the study by [58] showed that income level and employment status are the characteristics of the tourist that can most influence their level of satisfaction.

Finally, the results show a relationship between certain variables (sociodemographic characteristics-satisfaction), in line with those reported in other studies (e.g., [22,61]). In this case, important differences in overall satisfaction (factor 1) are only found with respect to gender (H1): women are more satisfied with the visit than men. On the other hand, the level of income is the variable that most influences satisfaction with the items corresponding to the other two factors used to measure satisfaction (H5): (2) satisfaction with road, hotel, restaurant and restoration infrastructure; and (3) satisfaction with information accessibility tourist and received treatment). Very different and contrary results have been obtained with the rest of the sociodemographic characteristics, such as age, employment status and the highest level of education, which have hardly influenced any item. Therefore, are not accepted of $\mathrm{H} 2, \mathrm{H} 3$ and $\mathrm{H} 4$.

At the same time, the investigation also identified the Segóbriga tourist (complete cultural tourist) as a middle-aged person (between 40 and 59 years), usually a woman, with higher education, a fairly high income level and a salaried employee. Thus, the results from this study enable a definition of the tourist who visits Segóbriga, the profile coincides with the first type of cultural tourist in the classification proposed by [34].

\section{Conclusions}

The data obtained on tourism in Spain reflects the fundamental role played by cultural tourism in the attractiveness of tourist destinations. Therefore, an important part of the tourism product is culture, which can increase the competitiveness of a destination. Culture should thus be appreciated as an element of major importance when creating a tourism product that reinforces sustainable tourism development.

The review of the literature provided some theoretical inferences about the places that have a rich heritage and cultural wealth, and how these become sustainable tourist resources for the area in which they are located. Cultural tourism offers an alternative to the traditional "sun and sand" tourism, which has been hugely popular but is currently losing ground to other types of travel activity that address other interests. The need thus arose to study a heritage site such as the archaeological park of Segóbriga.

The objective was to analyze tourists' satisfaction with the services provided in the park, assessing the degree to which sociodemographic characteristics influence that satisfaction. That is, the objective was to identify the relationships between tourist satisfaction and sociodemographic variables, in particular age, gender, level of education, employment status and income level.

The results show that profile of the typical tourist visiting Segóbriga is a complete cultural tourist. Thus, it can be seen that the tourist who visits this archeological park is one who seeks a much deeper cultural experience, with culture being the main reason for his/her visit. Indeed, the location of Segóbriga means that it is a place where tourists would only visit if they had specifically planned to go there; that is, the tourist knows perfectly well what they are looking for with a visit to this park - culture. On the other hand, the results shown that cultural tourism rests on a visitor profile that demands good infrastructure, a good provision of guides and information (panels, reenactments, museums) on the park, and mid-level accommodation and catering services. It is worth taking all these characteristics of the tourist profile into account, in order to ensure the loyalty and satisfaction of tourists to the archaeological park, and thus support the sustainable economic development of the area. 
Some practical implications can thus be offered. Tourists are becoming increasingly well-informed, more demanding and with a more multimotivational profile. Their loyalty is not guaranteed and there is growing competition aimed at capturing that loyalty; as such, the management of any destination should strive to meet the multiple motivations and interests of tourists. The cultural tourist may have a special responsiveness to the place he/she visits, however the underlying motivation is driven by leisure or free time. Thus, as far as services are concerned, the implementation of more complete interpretation centers along with the application of new technologies would be a worthwhile initiative for these types of cultural destinations.

Based on the results obtained, a revitalization plan can be proposed for the Segóbriga archaeological park, involving specific action plans for improvement, both in the services offered and in the image, and aimed at the creation of a high-quality sustainable tourism product. In short, in order to positively influence the tourists' behavioral intentions, heritage managers should make it a priority to ensure high experiential quality that creates satisfactory experiences for tourists, meaning that they perceive the visit as good value and leave with a good impression of the cultural heritage site.

Regarding future lines of research, this research is only a first step towards a complete analysis of sociodemographic factors and satisfaction. Future research should develop complementary indicators to analyze the effects of different socioeconomic and demographic factors of the tourist on their satisfaction, as well as other variables such as the motivation for their visit. Regarding the socioeconomic and demographic variables, studies could examine the tourist's culture, place of origin, whether they are a resident in the areas near the site, whether they are staying overnight in the area, etc. In this way, a more complete profile of the cultural tourist could be defined. Such a study could also shed new light on problems to be addressed in order to improve tourism in the area where this archaeological park is located. It could also be worth studying other archaeological sites with the same characteristics located in different countries, thus enabling a comparison between them, and providing valuable information on the competitiveness of heritage sites. Another interesting aspect is the analysis of the role that local residents play in the satisfaction of visitors to Segóbriga.

The limitations of this study relate to the selection of variables; it would have been interesting to study the role of the cultural tourist's motivations and emotions that set them apart from other types of tourist. There are many such variables, as well as the relationships between them, which have not been included in this study; some of these may represent future lines of research.

Supplementary Materials: The following are available online at http://www.mdpi.com/2071-1050/11/23/6774/s1, questionnaire, exploratory factor analysis (EFA) and univariate analysis of variance (ANOVA). Table 1 . Types of cultural tourists, Table 2. Factors for measuring satisfaction and individual items, Table 3. Results of the ANOVA analysis: sociodemographic characteristics-satisfaction.

Author Contributions: All authors contributed equally to the research.

Funding: This research received no external funding.

Conflicts of Interest: The authors declare no conflicts of interest.

\section{References}

1. Ministry of Energy and Tourism. Consultada el 15 de Enero de 2019. Available online: http://www.minetad.gob.es/es-ES/GabinetePrensa/NotasPrensa/2019/Paginas/Espa\%C3\%B1alograunr\% C3\%A9corddellegadasen2017con82millonesdeturistasinternacionales.aspx (accessed on 15 January 2019).

2. García, R.M.R.; Espinosa, E.O.C.; Ruiz, J.A.C. Propuesta de las competencias profesionales en turismo desde el enfoque del empleador/Proposal of Professional Competencies in Tourism from the employer's approach. RIDE Rev. Iberoam. Investig. Desarro. Educ. 2019, 9, 195-214.

3. Gómez, M.; Imhoff, B.; Martín-Consuegra, D.; Molina, A.; Santos-Vijande, M.L. Language tourism: The drivers that determine destination choice intention among US students. Tour. Manag. Perspect. 2018, 27, 125-135. [CrossRef]

4. Radosavljević, U.; Kuletin Ćulafić, I. Use of Cultural Heritage for Place Branding in Educational Projects: The Case of Smederevo and Golubac Fortresses on the Danube. Sustainability 2019, 11, 5234. [CrossRef] 
5. UNESCO. International Conference "Innovative Policies for Heritage Safeguarding and Cultural Tourism Development". 2005. Available online: https://whc.unesco.org/en/events/258/ (accessed on 15 November 2019).

6. Chen, C.F.; Chen, F.S. Experience quality, perceived value, satisfaction and behavioral intentions for heritage tourists. Tour. Manag. 2010, 31, 29-35. [CrossRef]

7. Brida, J.G.; Monterubbianesi, P.D.; Zapata-Aguirre, S. Determinantes del grado de satisfacción en la visita a un atractivo cultural: El Caso del Museo de Antioquia-Colombia. Estud. Perspect. Tur. 2013, 22, 729-744.

8. Moualla, Y.; McPherson, G. Making Change towards Inclusive Societies: The Soft Power of Community Archaeology in Building Cultural Heritage in Mozan, Syria. Sustainability 2019, 11, 4670. [CrossRef]

9. Aleshinloye, K.D.; Fu, X.; Ribeiro, M.A.; Woosnam, K.M.; Tasci, A.D. The Influence of Place Attachment on Social Distance: Examining Mediating Effects of Emotional Solidarity and the Moderating Role of Interaction. 2019. Available online: https://journals.sagepub.com/doi/abs/10.1177/0047287519863883 (accessed on 15 November 2019).

10. Patwardhan, V.; Ribeiro, M.A.; Payini, V.; Woosnam, K.M.; Mallya, J.; Gopalakrishnan, P. Visitors' Place Attachment and Destination Loyalty: Examining the Roles of Emotional Solidarity and Perceived Safety. 2019. Available online: https://journals.sagepub.com/doi/abs/10.1177/0047287518824157 (accessed on 16 November 2019).

11. Tasci, A.D.; Severt, D. A triple lens measurement of host-guest perceptions for sustainable gaze in tourism. J. Sustain. Tour. 2017, 25, 711-731. [CrossRef]

12. Torralba, L.T. La dimensión turística del patrimonio cultural de la ciudad de Lorca (Murcia, España). Cuad. Tur. 2015, 36, 389-414. [CrossRef]

13. Folgado Fernández, J.A.; Di Clemente, E.; Hernández Mogollón, J.M.; Campón Cerro, A.M. Influencia de la imagen del destino en el comportamiento del turista cultural. Un estudio empírico en la ciudad de Plasencia como destino de turismo cultural. Rev. Estud. Econ. Empres. 2013, 25, 91-114.

14. Van der Ark, L.A.; Richards, G. Attractiveness of cultural activities in European cities: A latent class approach. Tour. Manag. 2006, 27, 1408-1413. [CrossRef]

15. Pulido-Fernández, J.I.; Sánchez-Rivero, M. Attitudes of the cultural tourist: A latent segmentation approach. J. Cult. Econ. 2010, 34, 111-129. [CrossRef]

16. Silberberg, T. Cultural tourism and business opportunities for museums and heritage sites. Tour. Manag. 1995, 16, 361-365. [CrossRef]

17. Devesa Fernández, M.; Laguna García, M.; Palacios Picos, A. Un modelo estructural sobre la influencia de las motivaciones de ocio en la satisfacción de la visita turística. Rev. Psicol. Trab. Organ. 2008, 24, 253-268. [CrossRef]

18. Devesa Fernández, M.; Laguna García, M.; Palacios Picos, A. Motivación, satisfacción y lealtad en el turismo: El caso de un destino de interior. 2010. Available online: http://reme.uji.es/articulos/numero35/article9/ article9.pdf (accessed on 15 January 2019).

19. Perović, Đ.; Stanovčić, T.; Moric, I.; Pekovic, S. What socio-demographic characteristics do influence the level of tourist's satisfaction in Montenegro? Empirical analysis. Rev. Tur. Stud. Cercet. Tur. 2012, 14, 5-10.

20. Cordero, V.B.; Duque, C.M.; Muñoz, J.J.F.; Pocinho, R.F.D.S. Relaciones entre factores sociodemográficos-género-edad, nacionalidad, motivación y satisfacción turística: Análisis exploratorio en una muestra de turistas de la ciudad de Madrid. Rev. Anál. Tur. 2015, 20, 39-45.

21. Assaker, G.; Hallak, R.; Assaf, A.G.; y Assad, T. Validating a Structural Model of Destination Image, Satisfaction, and Loyalty Across Gender and Age: Multigroup Analysis with PLS-SEM. Tour. Anal. 2015, 20, 577-591. [CrossRef]

22. Yoon, Y.; Uysal, M. An examination of the effects of motivation and satisfaction on destination loyalty: A structural model. Tour. Manag. 2005, 26, 45-56. [CrossRef]

23. Hunter, C. Sustainable tourism as an adaptive paradigm. Ann. Tour. Res. 1997, 24, 850-867. [CrossRef]

24. Saarinen, J. Traditions of sustainability in tourism studies. Ann. Tour. Res. 2006, 33, 1121-1140. [CrossRef]

25. Sharpley, R. Tourism Development and the Environment: Beyond Sustainability? Routledge: Abingdon, UK, 2009; pp. 1-241.

26. Lu, J.; Nepal, S.K. Sustainable tourism research: An analysis of papers published in the Journal of Sustainable Tourism. J. Sustain. Tour. 2009, 17, 5-16. [CrossRef] 
27. Weaver, D.B. Asymmetrical dialectics of sustainable tourism: Toward enlightened mass tourism. J. Travel Res. 2014, 53, 131-140. [CrossRef]

28. Bunakov, O.A.; Zaitseva, N.A.; Larionova, A.A.; Chudnovskiy, A.D.; Zhukova, M.A.; Zhukov, V.A. Research on the evolution of management concepts of sustainable tourism and hospitality development in the regions. J. Sustain. Dev. 2015, 8, 39. [CrossRef]

29. Niemczyk, A. Cultural tourists: “An attempt to classify them". Tour. Manag. Perspect. 2013, 5, $24-30$. [CrossRef]

30. Altunel, M.C.; Erkut, B. Cultural tourism in Istanbul: The mediation effect of tourist experience and satisfaction on the relationship between involvement and recommendation intention. J. Destin. Mark. Manag. 2015, 4, 213-221.

31. Richards, G. (Ed.) Cultural Attractions and European Tourism; CAB International: Wallingford, UK, 2001.

32. Adams, G.D. Cultural tourism: The arrival of the intelligent traveler. Mus. News 1995, 74, 32-37.

33. Hughes, H.L. Culture and tourism: A framework for further analysis. Manag. Leisure 2002, 7, $164-175$. [CrossRef]

34. McKercher, B.; Du Cros, H. Cultural Tourism: The Partnership between Tourism and Cultural Heritage Management; Routledge: Abingdon, UK, 2002.

35. Caro, J.L.; Luque, A.; Zayas, B. Nuevas tecnologías para la interpretación y promoción de los recursos turísticos culturales. Pasos Rev. Tur. Y Patrim. Cult. 2015, 13, 931-945.

36. Hierro, J.A. Activos culturales y desarrollo sostenible: La importancia económica del Patrimonio Cultural. Política Soc. 2013, 50, 1133-1148.

37. Mckercher, B.; Du Cros, H. Testing a cultural tourism typology. Int. J. Tour. Res. 2003, 5, 45-58. [CrossRef]

38. Mckercher, B.; Ho, P.; Du Cros, H. Relationship between tourism and cultural heritage management: Evidence from Hong Kong. Tour. Manag. 2005, 26, 539-548. [CrossRef]

39. Kim, S.S.; Lee, C.K.; y Klenosky, D.B. The influence of push and pull factors at Korean national parks. Tour. Manag. 2003, 24, 169-180. [CrossRef]

40. Gregori PE, M.; Jarauta, N.G. Perfil del turista cultural en ciudades patrimoniales: Los casos de San Cristóbal de La Laguna y Córdoba (España). Int. J. Sci. Manag. Tour. 2015, 1, 217-229.

41. Richards, G. Cultural tourism. In Archaeological Displays and the Public; Routledge: Abingdon, UK, 2016; pp. 1-11.

42. Jelinčić, D.A.; Mansfeld, Y. Applying Cultural Tourism in the Revitalisation and Enhancement of Cultural Heritage: An Integrative Approach. In Cultural Urban Heritage; Springer: Cham, Switzerland, 2019; pp. 35-43.

43. Wolin, L.D.; Korgaonkar, P. Web advertising: Gender differences in beliefs, attitudes and behavior. Internet Res. 2003, 13, 375-385. [CrossRef]

44. Baloglu, S. A path analytic model of visitation intention involving information sources, socio-psychological motivations, and destination image. J. Travel Tour. Mark. 2000, 8, 81-90. [CrossRef]

45. MacKay, K.J.; y Fesenmaier, D.R. Pictorial element of destination in image formation. Ann. Tour. Res. 1997, 24, 537-565. [CrossRef]

46. Tasci, A.D.A. Assessment of Destination Image Determinants Using a Multiple Regression Model. Tour. Rev. 2007, 62, 23-30. [CrossRef]

47. Tasci, A.D.A.; Khalilzadeh, J.; Uysal, M. Network Analysis of the Caucasus' Image. Curr. Issues Tour. 2017, 22, 827-852. [CrossRef]

48. Tasci, A.D.A. Consumer demand for sustainability benchmarks in tourism and hospitality. Tour. Rev. 2017, 72, 375-391. [CrossRef]

49. Tasci, A.D.A. Testing the cross-brand and cross-market validity of a consumer-based brand equity (CBBE) model for destination brands. Tour. Manag. 2018, 65, 143-159. [CrossRef]

50. Esu, B.B.; Arrey, V.M.E. Tourists' satisfaction with cultural tourism festival: A case study of Calabar Carnival Festival, Nigeria. Int. J. Bus. Manag. 2009, 4, 116. [CrossRef]

51. Chon, K.S. The role of destination image in tourism: A review and discussion. Tour. Rev. 1990, 45, $2-9$. [CrossRef]

52. Echtner, C.M.; Y Ritchie, J.R.B. The meaning and measurement of destination image. J. Tour. Stud. 1991, 2, 2-12.

53. Varela Mallou, J.; Prat Santolària, R.; Voces López, C.; Rial Boubeta, A. Una nueva escala para la evaluación de la calidad de los servicios de hostelería. Psicothema 2006, 18, 135-142. [PubMed] 
54. Chon, K.S.; Olsen, M.D. Functional and symbolic congruity approaches to consumer satisfaction/dissatisfaction in tourism. J. Int. Acad. Hosp. Res. 1991, 3, $2-22$.

55. Bigné, J.E.; Andreu, L. Modelo cognitivo-afectivo de la satisfacción en servicios de ocio y turismo. Cuad. Econ. Dir. Empresa 2004, 21, 84-120.

56. Ahmed, Z.U. The influence of the components of a state's tourist image on product positioning strategy. Tour. Manag. 1991, 12, 331-340. [CrossRef]

57. Baloglu, S.; y McCleary, K.W. A model of destination image formation. Ann. Tour. Res. 1999, $26,868-897$. [CrossRef]

58. Beerli, A.; y Martin, J.D. Tourists characteristics and the perceived image of tourist destinations: A quantitative analysis-A case study of Lanzarote, Spain. Tour. Manag. 2004, 25, 623-636. [CrossRef]

59. Huh, J. Tourist Satisfaction with Cultural/Heritage Sites: The Virginia Historic Triangle. Ph.D. Thesis, Virginia Polytechnic Institute and State University, Blacksburg, VA, USA, 2002.

60. Faullant, R.; Matzler, K.; Mooradian, T.A. Personality, basic emotions, and satisfaction: Primary emotions in the mountaineering experience. Tour. Manag. 2011, 32, 1423-1430. [CrossRef]

61. Del Bosque, I.A.R.; San Martín, H.; Collado, J. The role of expectations in the consumer satisfaction formation process: Empirical evidence in the travel agency sector. Tour. Manag. 2006, 27, 410-419. [CrossRef]

(C) 2019 by the authors. Licensee MDPI, Basel, Switzerland. This article is an open access article distributed under the terms and conditions of the Creative Commons Attribution (CC BY) license (http://creativecommons.org/licenses/by/4.0/). 